\title{
Fertiliser use in the Bay of Plenty, Waikato and South Auckland regions
}

\author{
P.J. BUTLER ${ }^{1}$ and T.J. JOHNSTON ${ }^{2}$ \\ BOP Fertiliser Ltd, ${ }^{\text {I }}$ ukekohe, ${ }^{2}$ Mt Maunganui
}

\begin{abstract}
In the area from Taupo to Auckland, and North Island wide, BOP Fertiliser Ltd, Mt Maunganui, supplies some $700000 \mathrm{t}$ of fertiliser annually. In the years 1994/95, 1995/96 and 1996/97 total fertiliser sales were 668900,700700 and 678100 respectively. BOP Fertiliser supplied fertiliser to approximately $50 \%$ of New Zealand dairy farms. Nitrogen was applied to $91 \%$ of dairy farms at an average annual input of $58 \mathrm{~kg} \mathrm{~N} / \mathrm{ha}$. Less than $4 \%$ of farms applying $\mathrm{N}$ received $>200 \mathrm{~kg} \mathrm{~N} / \mathrm{ha}$. Some $23 \%$ of dairy farms received less than maintenance $\mathrm{P}(30 \mathrm{~kg} / \mathrm{ha})$. A review of soil fertility levels on dairy farms in 1996/97 using soil test results from the Soil Fertility Service laboratories at Ruakura suggests some $38 \%$ of Olsen $\mathrm{P}$ values on dairy farms were below optimum $(<30), 49 \%$ of $\mathrm{pH}$ tests were $<5.8,55 \%$ of $\mathrm{K}$ tests were $<8,30 \%$ of S tests were $<12$ and $8 \%$ of $\mathrm{Mg}$ tests were $<15$. Likewise on sheep-beef farms some $43 \%$ of the land received less than maintenance $\mathrm{P}(15 \mathrm{~kg} \mathrm{P})$ while soil fertility levels indicated $54 \%$ of Olsen $\mathrm{P}$ values were below optimum $(<17) ; 69 \%$ of the pHs were $<5.8 ; 42 \%$ of the K tests were $<5 ; 29 \%$ of the $\mathrm{S}$ tests were $<8$ and $12 \%$ of the $\mathrm{Mg}$ tests were $<8$. Figures for South Auckland follow a similar pattern to the region. Trace element use indicated $26 \%$ of the farms used Co, $37 \%$ used Se, $13 \%$ boron and $9 \%$ copper. Pasture analyses records for 1996/97 (Ruakura SFS Laboratories) suggest trace element use follows deficiencies in a general way.
\end{abstract}

Keywords: database, dairy farms, fertilisers, nutrient status, sheep-beef farms, trace elements

\section{Introduction}

The Bay of Plenty Co-operative Fertiliser Company began production from its Mt Maunganui plant in 1958. In 1987 it became BOP Fertiliser Ltd in a merger between the Co-operative and FERNZ. BOP operates in an area from Taupo to Auckland, North Island wide, supplying half of New Zealand's dairy farmers with fertiliser. It is estimated that the company supplies over $90 \%$ of the fertiliser used in the region. The Mt Maunganui works produces approximately $700000 \mathrm{t}$ of fertiliser annually and is the highest-producing single plant fertiliser in Australasia. A recent Company initiative, as part of its customer support focus, has been to use fertiliser sales together with farm type and area data from its customers to provide information on the quantities of nutrients applied per farm and per ha. This includes major nutrients $\mathrm{N}, \mathrm{P}, \mathrm{K}, \mathrm{S}$, and $\mathrm{Mg}$ and trace elements cobalt, selenium, copper, and boron. This paper provides information on the nutrients applied in 1996/97 from an analysis of 11000 shareholder records within the BOP Fertiliser sales area (excluding recent acquisitions). Fertiliser inputs on dairy and sheep-beef properties are considered in relation to current fertility status as gauged from soil tests.

\section{Methods}

Farmer shareholder sales information was used together with farm type, farm area, location and regional council boundaries to provide an information base. Such data includes: number of shareholders $\times$ farm type, average nutrients applied per ha $\times$ farm type, $\%$ of farms using nutrients $\mathrm{N}, \mathrm{P}, \mathrm{K}, \mathrm{S}$ and $\mathrm{Mg}$, total nutrients applied per ha and per farm, and trace elements applied (cobalt, copper, selenium and boron).

The soil fertility status of soils in BOP Fertiliser sales region was assessed from the AgResearch Soil Fertility Service soil test records at Ruakura. Some 3340 soil test records were available.

\section{Results and discussion}

\section{Total fertiliser sales}

Total fertiliser sales (tonnes) and nutrient component (tonnes) are shown in Table 1. Records were obtained from $78 \%$ of the customers and account for $88 \%$ of the fertiliser sold. Total sales have been reasonably consistent over the past three years with a high in 1995/ 96. Nitrogen sales increased by $13 \%$ between $1994 / 95$ and 1995/96 and remained constant in 1996/97. Other nutrient sales have remained relatively constant over the three years. 


\section{Total nutrients applied $\times$ farm type}

The average annual rate of nutrient applied $(\mathrm{N}, \mathrm{P}, \mathrm{K}, \mathrm{S}$, $\mathrm{Mg}$ ) according to farm type is shown in Table 2.

\section{Nitrogen}

The average $\mathrm{N}$ input on dairy farms was $58 \mathrm{~kg} \mathrm{~N} / \mathrm{ha}$. This varied between regions, with Matamata-Piako, Waipa, Tauranga, and Rotorua averaging $65-71 \mathrm{~kg} \mathrm{~N} /$ ha while Franklin, Hauraki and Thames-Coromandel averaged $40-44 \mathrm{~kg} / \mathrm{ha}$. Some $91 \%$ of dairy farms applied $\mathrm{N}$. High rates of $\mathrm{N}$ input were limited to a small number of farms as shown in Table 3, over $70 \%$ of farms applying less than $100 \mathrm{~kg} \mathrm{~N} / \mathrm{ha}$.

$\mathrm{N}$ use on sheep and beef farms is still low, averaging $4 \mathrm{~kg} \mathrm{~N} / \mathrm{ha}$. The apparent high $\mathrm{N}$ input on vegetable crops, averaging $244 \mathrm{~kg} \mathrm{~N} / \mathrm{ha}$, is of particular interest to the Pukekohe region where research is concentrating on possible ways of minimising environmental impacts (Crush et al. 1997).

\section{Phosphorus and sulphur}

$\mathrm{P}$ inputs in dairying averaged $56 \mathrm{~kg} \mathrm{P} / \mathrm{ha}$, which is considered a good maintenance application. Even so, some $23 \%$ of dairy farms were applying less than $30 \mathrm{~kg}$ $\mathrm{P} / \mathrm{ha}$, which would be considered a minimum input for maintenance. Average P inputs on sheep-beef farms at $24 \mathrm{~kg} \mathrm{P} / \mathrm{ha}$ is also considered a good maintenance level. However, $43 \%$ of farms received less than $15 \mathrm{~kg} \mathrm{P} / \mathrm{ha}$, which is considered below maintenance. Again, very high $\mathrm{P}$ inputs are seen in vegetable crops. The pattern for $\mathrm{S}$ inputs is very similar to that of $\mathrm{P}$ applications for most situations.

\section{Potassium}

$\mathrm{K}$ inputs in dairying averaged $69 \mathrm{~kg} \mathrm{~K} / \mathrm{ha}$, which is considered a good maintenance application. Inputs of $\mathrm{K}$ on sheep-beef properties is still relatively low but nevertheless significant. Vegetable crops continue to receive high inputs of $K$ and some $K$ appears to be applied to tree crops.

\section{Magnesium}

$\mathrm{Mg}$ inputs in dairying, sheep-beef and forestry are relatively low. There is opportunity to increase $\mathrm{Mg}$ inputs, particularly in dairying and sheep-beef situations where Mg soil test levels are falling (M.B. O'Connor, pers. comm.).

\section{Soil fertility status of dairy and sheep-beef farms in BOP Fertiliser supply region - 1996}

AgResearch Soil Fertility Service records have been analysed for both dairy and sheep-beef farm samples in the BOP Fertiliser supply region. Results (Table 4)
Table 1 Fertiliser and nutrient sales: 1994/95-1996/97.

\begin{tabular}{llrrr}
\hline & & $1994 / 95$ & $1995 / 96$ & $1996 / 97$ \\
\hline Total sales & & 668889 & 700735 & 678104 \\
Nutrient sales & $\mathrm{N}$ & 39791 & 44788 & 44098 \\
& $\mathrm{P}$ & 52024 & 53544 & 49371 \\
& $\mathrm{~K}$ & 51445 & 53452 & 52099 \\
& $\mathrm{~S}$ & 57848 & 60294 & 55898 \\
& $\mathrm{Mg}$ & 3709 & 3909 & 3671 \\
Total nutrients & & 204817 & 215987 & 205137 \\
\hline
\end{tabular}

Table 2 Nutrients applied $\times$ farm type $-1996 / 97$.

\begin{tabular}{|c|c|c|c|c|c|}
\hline \multirow[b]{2}{*}{ Farm type } & \multicolumn{5}{|l|}{$\mathrm{kg} / \mathrm{ha}$} \\
\hline & $\mathrm{N}$ & $P$ & K & $S$ & $\mathrm{Mg}$ \\
\hline Dairy & 58 & 56 & 69 & 67 & 4 \\
\hline Sheep-beef & 4 & 24 & 17 & 29 & 2 \\
\hline Vegetables & 244 & 167 & 165 & 136 & 44 \\
\hline Tree crops & 21 & 19 & 33 & 21 & 6 \\
\hline Average & 39 & 44 & 46 & 59 & 3 \\
\hline
\end{tabular}

Table $3 \mathrm{~N}$ application rates on dairy farms applying $\mathrm{N}-$ 1996/97.

\begin{tabular}{ccc}
\hline $\mathrm{kg} \mathrm{N} / \mathrm{ha}$ & No. of farms & \% of farms \\
\hline$<100$ & 4176 & 73.9 \\
$100-150$ & 911 & 16.2 \\
$150-200$ & 352 & 6.2 \\
$200-300$ & 153 & 2.7 \\
$300+$ & 58 & 1.0 \\
Total & $\mathbf{5 6 5 0}$ & $\mathbf{1 0 0}$ \\
\hline
\end{tabular}

show that although average values are similar to or better than optimum, there are a number below optimum. The average fertility status has remained relatively static over the past 2 years, with some $38 \%$ of dairy farm samples still below optimum for $\mathrm{P}$ in 1996. The increased number of farm samples below optimum for $\mathrm{K}$ and $\mathrm{S}$ in the last two years may have been owing to the relatively wet winters experienced in those years. On sheep-beef farms a similar trend was evident, some $54 \%$ of farms being below optimum for $\mathrm{P}$. Of concern also was the number of farms with $\mathrm{pH}$ below optimum (Table 4).

In South Auckland mean soil test levels from dairy farm samples tended to be similar for $\mathrm{P}$ and $\mathrm{K}, \mathrm{S}$ and $\mathrm{Mg}$ levels being somewhat higher than the regional levels. Sheep-beef farm samples showed a similar trend, although $S$ levels appeared to be lower. This may reflect a dominance of sedimentary soils used for sheep-beef in South Auckland as opposed to volcanic soils in the region. 
Table 4 Soil fertility status - BOP Fertiliser supply region and South Auckland, 1995-1996.

\begin{tabular}{|c|c|c|c|c|c|}
\hline Element & Optimum & 1995 & $\begin{array}{l}\text { an soil tes } \\
\% \text { below } \\
\text { optimum }\end{array}$ & 1996 & \% below \\
\hline \multicolumn{6}{|l|}{ Dairy } \\
\hline $\mathrm{pH}$ & 5.8 & 5.8 & 51 & $5.6(5.9)$ & 49 (44) \\
\hline $\mathrm{P}$ & 30 & 41 & 32 & $39(35)$ & 38 (42) \\
\hline K & 8 & 8 & 60 & $8(8)$ & 55 (22) \\
\hline$S$ & 12 & 27 & 29 & $11(21)$ & 75 (48) \\
\hline $\mathrm{Mg}$ & 15 & 21 & 40 & $20(24)$ & 8 (15) \\
\hline \multicolumn{6}{|c|}{ Sheep-beef } \\
\hline $\mathrm{pH}$ & 5.6 & 5.7 & 34 & $5.7 \quad(5.8)$ & 69 (22) \\
\hline $\mathrm{P}$ & 17 & 23 & 45 & $23(22)$ & 54 (52) \\
\hline K & 5 & 7 & 43 & $7(7)$ & 42 (24) \\
\hline$S$ & 8 & 17 & 29 & $18(9)$ & 29 (45) \\
\hline $\mathrm{Mg}$ & 8 & 21 & 12 & $21(26)$ & $12(0)$ \\
\hline
\end{tabular}

Table 5 Percentage of farmers using trace elements $(B, C O$, $\mathrm{Cu}, \mathrm{Se}) \times$ farm type in the BOP Fertiliser supply region $-1996 / 97$.

\begin{tabular}{ccrccc}
\hline Trace element & Dairy & Beef & Sheep & Other livestock & Mean \\
\hline B & 12 & 8 & 15 & 10 & 13 \\
Co & 22 & 24 & 41 & 29 & 26 \\
Cu & 7 & 4 & 3 & 12 & 9 \\
Se & 39 & 20 & 23 & 26 & 37 \\
\hline
\end{tabular}

Table 6 Trace element status in the BOP Fertiliser Ltd region -1996/97. (SFS, Ruakura records)

\begin{tabular}{cccc}
\hline Trace element & Critical level & $\begin{array}{c}\text { \% below } \\
\text { optimum }\end{array}$ & $\begin{array}{c}\text { \% above } \\
\text { optimum }\end{array}$ \\
\hline B mixed herbage & 6 & 47 & 41 \\
clover only & 13 & 0 & 100 \\
Co & 0.08 & 13 & 73 \\
Cu & 5 & 18 & 69 \\
Se & 0.03 & 40 & 30 \\
\hline
\end{tabular}

\section{Percentage of farmers using trace elements}

The percentage of farmers using the trace elements B, $\mathrm{Co}, \mathrm{Cu}$ and $\mathrm{Se}$ in the BOP region in 1996/97 is shown in Table 5. The bulk of the B was applied to farms in the Rotorua-Taupo region, presumably on brassica crops and some lucerne. Co use was widespread on the pumice soils of Rotorua-Taupo/Bay of Plenty but also extensive through Otorohanga, South Waikato and Waitomo counties on all farm types. $\mathrm{Cu}$ was used predominantly on Waikato dairy farms and Se use was widespread over all counties.
An analysis of the AgResearch Soil Fertility Service herbage data for 1996/97 (Table 6) indicates that Se is the most deficient trace element in the region and this is reflected in use figures (Table 5). Co and $\mathrm{Cu}$ showed an approximately equal number of deficient samples, yet $\mathrm{Cu}$ fertiliser use was still relatively low. B requirement for brassicas and lucerne is well established. There is no evidence to suggest that B deficiency in pastures is occurring in the region. In this regard it is important that clover-only samples are analysed as mixed pasture samples can be quite misleading (Table 6).

\section{Summary}

BOP Fertiliser Ltd sales in 1996/97 totalled 678,104 t, the average rate of nutrients applied being $39 \mathrm{~kg} \mathrm{~N}, 44$ $\mathrm{kg} \mathrm{P}, 46 \mathrm{~kg} \mathrm{~K}, 59 \mathrm{~kg} \mathrm{~S}$ and $3 \mathrm{~kg} \mathrm{Mg} / \mathrm{ha}$. In dairying 91\% of farmers used $\mathrm{N}$, the average rate of application being $58 \mathrm{~kg} / \mathrm{ha}$. Some $73 \%$ of farms used less than $100 \mathrm{~kg} \mathrm{~N} /$ ha, less than $4 \%$ of farms using greater than $200 \mathrm{~kg} \mathrm{~N} /$ ha. In South Auckland approximately $42 \%$ of the Olsen $\mathrm{P}$ tests on dairy farms and $52 \%$ on sheep farms were below optimum. This was higher than the regional average for dairy farms but similar for sheep-beef farms. Trace element use generally followed the pattern of deficiency noted in the laboratory records, i.e., mainly $\mathrm{Se}$ and to a lesser extent Co. The South Auckland region followed a similar pattern. Information on nutrients applied to different farm types provides useful information to a range of end-users.

\section{ACKNOWLEDGEMENTS}

Thanks are owing to Mike O'Connor for assistance in the preparation of this paper and to Warren Brown, Comtech Services, Morrinsville for the preparation of the fertiliser statistics.

\section{REFERENCES}

Crush, J.R.; Cathcart, S.N.; Singleton, P.; Longhurst, R.D. 1997. Potential for nitrate leaching from different land uses in the Pukekohe area. Proceedings of the New Zealand Grassland Association 59: (in press). 
